\title{
Processes Analysis of Networks Management Systems
}

\author{
Lubomyr Petryshyn \\ dept. of Enterprise Management \\ AGH University of Science \\ and Technology \\ Cracow, Poland \\ 1.b.petryshyn@gmail.com \\ ORCID: 0000-0003-4168-3891
}

\author{
Wioleta Cieslik \\ dept. of Computer Science \\ AGH University of Science \\ and Technology \\ Cracow, Poland \\ w.cieslik@gmail.com
}

\author{
Mykhailo Petryshyn \\ dept. of Computer Science \\ and Information Systems \\ Precarpathian National University \\ Ivano-Frankivsk, Ukraine \\ m.l.petryshyn@gmail.com \\ ORCID: 0000-0001-6319-3768
}

\section{Analizy Procesowa Sieciowych Systemów Zarządzania}

\author{
Lubomyr Petryshyn \\ kat. Zarządzania Przedsiębiorstwem \\ AGH University of Science \\ and Technology \\ Kraków, Polska \\ 1.b.petryshyn@gmail.com \\ ORCID: 0000-0003-4168-3891
}

\author{
Wioleta Cieślik \\ kat. Informatyki Stosowanej \\ AGH University of Science \\ and Technology \\ Kraków, Polska \\ w.cieslik@gmail.com
}

\author{
Mykhailo Petryshyn \\ kat. Nauk Komputerowych \\ i Systemów Informatycznych \\ Precarpathian National University \\ Ivano-Frankivsk, Ukraina \\ m.l.petryshyn@gmail.com \\ ORCID: 0000-0001-6319-3768
}

\begin{abstract}
Adnotacja-Modelowanie procesów zarządzania w warunkach kooperacji sektorowej na podstawie rozproszonych systemów informatycznych pozwala zmniejszyć koszty opracowania i eksploatacji takich złożonych systemów. Proponowana technika analizy procesowej pozwala na dekompozycję calościowego procesu systemu zarządzania oraz na wizualizację modeli informacyjnych oraz odwzorowanie w formie graficznej procesów i upraszcza porozumienie się na etapie analizy i projektowania pomiędzy klientem a producentem systemu. Przedstawiono podstawy analizy systemowej i uproszczony przyklad opracowania systemu zarządzania siecią dostaw produkcji.
\end{abstract}

Stowa kluczowe-analiza procesowa, modelowanie wizualizacyjne, procesy informacyjne, kooperacja sektorowa, systemy rozproszone, zarzadzanie

Abstract-Simulation of the processes of sectoral cooperation management in distributed information systems allows to reduce the means of introduction and operation of such complex systems. The proposed method of visualization of information models reflects graphically the constituent processes and simplifies the understanding at the stage of analysis and design between the customer and the system developer. The basics of visualization modeling and simplified example of models development of multi-sectoral management system are presented.

Keywords—process analysis, visualization modeling, information processes, sectoral cooperation, distributed systems, management

\section{WSTĘP}

Zarządzanie złożonymi systemami w warunkach kooperacji sektorowej wymaga zastosowania technologii informacyjnej, która zapewnia odwzorowanie stanu systemu i umożliwia zarządzanie systemem w czasie rzeczywistym. Analiza oraz wizualizacja procesów zarządzania pozwala na usunięcie bariery psychologicznej i uniknięcie nieporozumienia pomiędzy klientem i twórcą systemów informatycznych, a także pozwala zmniejszyć koszty opracowania, wdrażania i obsługi takich złożonych systemów.

Celem opracowania jest przedstawienie techniki analizy procesowej jak podstawy wizualnych metod modelowania procesów zarządzania złożonymi systemami w warunkach kooperacji sektorowej, a także opracowanie uproszczonego przykładu systemu zarządzania siecią dostaw produkcji.

Nowacją pracy jest przedstawienie techniki analizy systemowej, która przy jej implementacji w trakcie modelowania informacyjnego systemów zapewnia wizualizację procesów zarządzania i upraszczają rozumienie ich przepływów.

Aspekt praktyczny polega na kompleksowej analizie struktury i przepływu procesów zarządzania, unikania nieporozumień przy formułowaniu zadania i zapewniania wymagań klienta, a także zmniejszania kosztów tworzenia i eksploatacji systemów zarządzania. W projekcie pozostał 
opracowany uproszczony przykład systemu zarządzania siecią dostaw produkcji gastronomicznej.

Podstawy modelowania wizualizacyjnego sac opublikowane w [1]. Przeanalizujemy uproszczony przykład modelowania rozproszonego systemu zarządzania siecią sprzedaży produkcji z punktów gastronomicznych w skali kraju w celu usprawnienia i ułatwienia potencjalnemu klientowi wyboru konkretnego zamówienia wg jego potrzeb $\mathrm{w}$ danej chwili. Innym aspektem jest wypromowanie początkujące punktów gastronomicznych i poszerzenie oferty sprzedażowej tych, które już prosperują na rynku.

$\mathrm{Na}$ początku zostanie przedstawiona analiza jednostek organizacyjnych portalu (rys. 1) oraz ich funkcje systemowe. $\mathrm{W}$ trakcie modelowania systemu korzystano $\mathrm{z}$ istniejących już systemów prezentujących podobną ofertę.

\section{ANALIZA POSZCZEGÓLNYCH JEDNOSTEK SYSTEMU}

\section{A. Zarząd}

Główną funkcją zarządu jest wybór dyrektora, oraz kontrola wyników, jakie firma osiąga pod jego władzą.

\section{B. Dyrektor}

Do zadań Dyrektora należy optymalne zarządzanie wszystkimi działami firmy.

\section{Dziat Sprzedazy}

Podstawową funkcją tego działu jest sprzedaż produktów i monitorowanie całego procesu sprzedaży, w szczególności zbieranie informacji o pozycjach najczęściej wybieranych przez klientów, najbardziej obleganych restauracji. Dział ten zarządza działem obsługi klienta, który dba o dobre relacje z klientem i rozpatruje wszelkie zgłoszone reklamacje.

\section{Dziat dostaw}

Zajmuje się nadzorem nad poprawnym przebiegiem procesu dostawy. Czuwa nad tym, aby zamówienie klienta dotarło do odpowiedniego dostawcy usług gastronomicznych i kontroluje dostawę zamówienia $\mathrm{Z}$ danego punktu gastronomicznego do klienta.

\section{E. Dziat finansów}

Zajmuje się finansami oraz rachunkowością w firmie.

\section{F. $H R$}

Podstawowa funkcją jest pozyskiwanie nowych pracowników, stworzenie możliwości rozwoju dla przyjętych już pracowników np. poprzez organizowanie szkoleń oraz dbanie o dobrą komunikację wewnętrzną. Ma na celu stworzenie dogodnych warunków pracy i zapewnienie rozwoju pracownikom.

\section{G. Dziat marketingu}

Zajmuję się organizowaniem promocji i opracowywaniem strategii marketingowych mających na celu przyciągnięcie nowych klientów i zatrzymanie obecnych. Zbiera informację i zajmuję się ich przetwarzaniem oraz dokonuje analiz w celu obrania najlepszej drogi do polepszenia jakości oferowanych usług.

Modelowany system jest kompleksowym serwisem do zamawiania produkcji online $\mathrm{z}$ dostawa pod podany adres, kumulujący ofertę mnóstwa współpracujących z nim punktów gastronomicznych. Model ten jest oparty na współpracujących ze sobą modułach: zamówienia, dostawa, finanse, marketing, analiza, sprzedaż, obsługa klienta, zniżka.

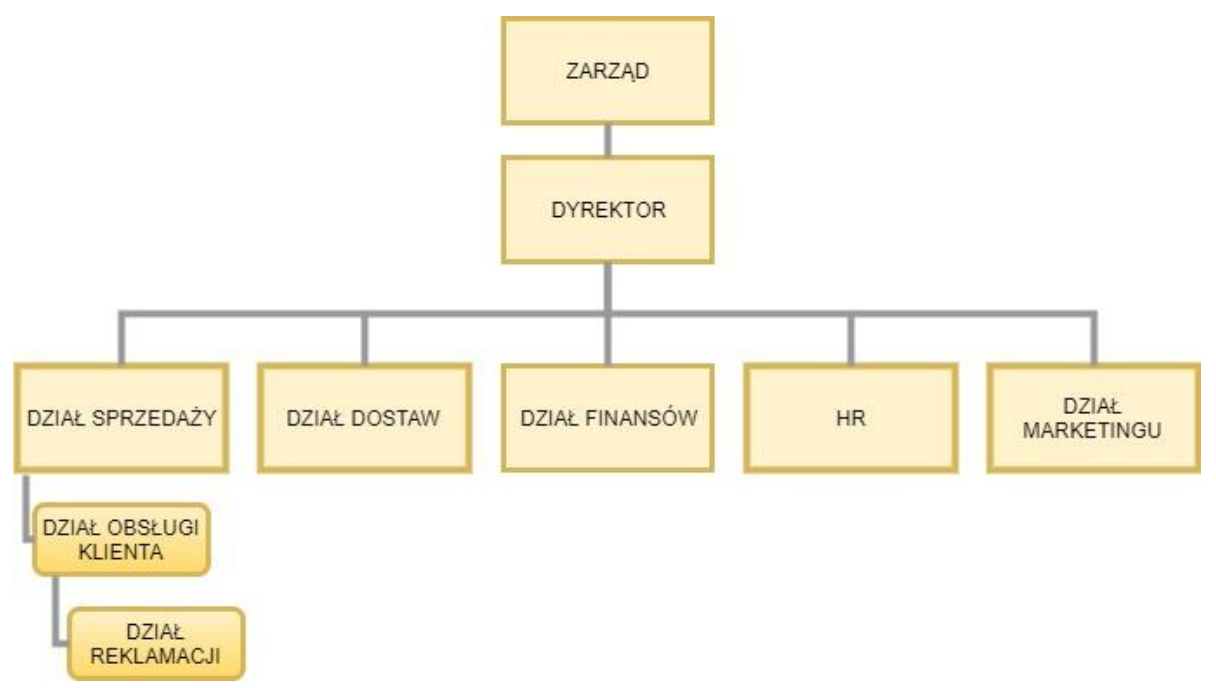

Rys. 1. Struktura organizacyjna i analiza funkcji poszczególnych jednostek systemu.

Celem działania systemu „Eat something” jest uproszczenie potencjalnemu klientowi złożenia zamówienia poprzez zestawienie mu wszystkich restauracji i umożliwienie łatwego wyboru odnosząc się do tego, na co w danej chwili ma ochotę. 


\section{ANALIZA FUNKCJONALNYCH WYMAGAŃ UŻYTKOWNIKÓW}

- Prowadzenie bazy danych punktów gastronomicznych i ich menu - poziomy cen, promocje, rabaty, opakowania zbiorcze, kalkulacja cen;

- Możliwość obsługi dowolnej liczby klientów;

- Przyjęcie zamówienia złożonego przez klienta;

- Przekazanie informacji o zamówieniu do konkretnego punktu gastronomicznego;

- Obsługa promocji i rabatów dla stałych klientów;

- Rejestracja użytkownika;

- Logowanie użytkownika;

- Modyfikowanie danych użytkownika;

- Integracja z systemami poszczególnych punktów gastronomicznych;

- Obsługa koszyka zamówień;

- Przechowywanie historii zamówień i ich stanów w celu ich późniejszej analizy;

- Obsługa kanału SMS;

- Obsługa kanału e-mail (promocje);

- Obsługa płatności PayU;

- Przegląd lokali i menu na podstawie wybranych filtrów;

- Umożliwienie wyboru pozycji, dodatków wg preferencji klienta w danej chwili;

- Umożliwienie wyboru adresu dostawy, sposobu płatności oraz specjalnych życzeń klienta co do dostawy;

- Dodawanie i usuwanie reklam promocyjnych pojawiających się na określony czas.

\section{ANALIZA NIEFUNKCJONALNYCH WYMAGAŃ UŻYTKOWNIKÓW}

- Baza danych oparta na technologii SQL client-server. W podstawowej wersji program jest dostępny dla Microsoft SQL Server;

- Dostępne są funkcje replikacji i kopii zapasowych baz danych;

- System współpracuje z aplikacjami: webową i mobilną;

- Aplikacja mobilna jest dostępna na: Android, iOS;

- Aplikacja webowa dostępna jest na wszystkich przeglądarkach;

- System hostingowany jest na platformie Home.pl;

- Hosting będzie zawierał system Ubuntu 64-bitowy;
- Obsługa serwera realizowana jest przez program Apache;

- Wszystkie requesty są szyfrowane za pomocą SSL'a;

- Backend zrealizowany w technologii Java Spring;

- Frontend zrealizowany w technologii AngularJS;

- System dostępny 24h i 7 dni w tygodniu;

- Maksymalny czas niedostępności systemu to $1 \mathrm{~h}$ w ciągu miesiąca;

- Zapewnia równoczesny dostęp 1000 użytkowników;

- Maksymalny czas reakcji wynosi 10 sekund;

- System powinien dać się łatwo rozszerzać;

- Obsługa 10000 transakcji tygodniowo.

\section{ANALIZA PROCESÓW ZARZACDZANIA SYSTEMEM}

A. Realizacja zamówienia

- Przyjęcie zamówienia złożonego przez klienta;

- Sprawdzenie czy trwają obecnie akcje promocyjne;

- Weryfikacja Klienta;

- Informacja zwrotna na temat udzielenia rabatu dla danego klienta;

- Zarejestrowanie transakcji;

- Przekazanie zamówienia do punktu gastronomicznego;

- Informacja zwrotna na temat realizacji zamówienia przez partnera;

- Powiadomienie klienta o czasie realizacji zamówienia.

B. Promocja

- Opracowanie kampanii promocyjnej;

- Ujęcie promocyjnych cen w systemie;

- Zebranie wyników do analiz w czasie trwania promocji;

- Przeprowadzenie analiz po promocji.

C. Złożenie zażalenia przez klienta (przypadek uznania)

- Informacja od klienta o nieprawidłowości zamówienia;

- Zaksięgowanie reklamacji w systemie;

- Poinformowanie punktu gastronomicznego;

- Informacja zwrotna $\mathrm{z}$ punktu gastronomicznego o uznaniu reklamacji;

- Informacja do klienta o uznaniu reklamacji.

VI. DEKOMPOZYCJA PROCESÓW ZARZĄDZANIA

Oznaczenia modułów systemu: 
M1 - zamówienia;

M2 - dostawa;

M3 - finanse;

M4 - marketing;

M5 - sprzedaż;

M6 - analiza;

M7 - obsługa klienta (support);

M8 - zniżka.

Definicja operacji systemowych:

D1.M1 - Zarejestrowanie zamówienia w systemie;

D1.M4 - Sprawdzenie czy trwa aktualnie kampania promocyjna na wybrany przez klienta produkt;

D1.M8 - Sprawdzenie czy dany klient jest uprawniony do rabatu i automatyczne przyznanie mu go;

D2.M1 - Otrzymanie informacji zwrotnej;

D3.M3 - Zaksięgowanie transakcji;

D3.M5 - Przesłanie zamówienia do punktu gastronomicznego, z którego klient wybrał zamówienie;

D3.M6 - Przesłanie danych do analizy;

D4.M1 - Otrzymanie informacji od punktu gastronomicznego;

D5.M2 - Powiadomienie klienta o czasie trwania dostawy;

D6.M4 - Opracowanie strategii promocyjnej;

D7.M1 - Ujęcie promocyjnych cen w systemie;

D8.M3 - Udokumentowanie promocji;

D9.M6 - Zebranie wyników do analiz w czasie trwania promocji i ocena promocji;

D10.M7 - Informacja od klienta o nieprawidłowości zamówienia;

D11.M1 - Zaksięgowanie reklamacji w systemie;

D12.M5 - Poinformowanie punktu gastronomicznego;

D13.M1 - Informacja zwrotna z punktu gastronomicznego o uznaniu reklamacji;
D14.M7 - Informacja do klienta o uznaniu reklamacji.

\section{PODSUMOWANIE}

W oparciu o opracowane metody wizualizacji przebiegu funkcjonowania złożonych systemów zarządzania w warunkach kooperacji sektorowej określono podstawy symulacji, które pozwoliły na prezentacje przebiegu procesów i umożliwiły zarządzanie systemem informacyjnym w czasie rzeczywistym. Opracowany materiał jest zintegrowaną częścią publikacji [2], która przedstawia metody oraz technikę wizualizacji procesów zarządzania, która $\mathrm{z}$ kolei pozwala usunąć barierę psychologiczną i uniknąć wzajemnego nieporozumienia między klientem i twórcą systemów informatycznych a także zmniejszyć koszty opracowania, wdrażania i obsługi rozproszonych systemów zarządzania.

Osiągnięto cel projektu, jakim była analiza procesowa systemu zarządzania portalem gastronomicznym. Dokonano dekompozycji systemu na podstawie analizy procesów zachodzących w rzeczywistości. Dzięki wdrożeniu systemu można zoptymalizować koszty, poprawić jakość obsługi oraz zautomatyzować procesy dostawy produkcji.

Wdrożenie opracowanego systemu pozwoliło na usprawnienie wymiany informacji między oddzielnymi jednostkami i przejście na elektroniczny system zarządzania. Wdrażanie zmian $\mathrm{w}$ systemie spowodowało wzrost konkurencyjności firmy, a funkcjonalność systemu dostosowano do standardów rynkowych.

\section{LITERATURA REFERENCES}

[1] Л. Петришин, Я. Николайчук, Аналитическое моделирование информационных систем автоматизированного управления Analytical modeling of infosystems of automated management. / Lyubomyr Petryshyn // Zarządzanie organizacjami w gospodarce rynkowej: X miedzynarodowa naukowa konferencja "Zarzadzanie przedsiębiorstwem. Teoria i praktyka": Kraków, 22-23 listopada 2007 r. / pod red. Wiesława Waszkielewicza; — Kraków: Wydawnictwa AGH, 2007. - ISBN 978-83-7464-153-1 - S. 268275. - Bibliogr. s. 338, Abstr.

[2] L. Petryshyn, W. Cieslik, M. Petryshyn. Visualization Modeling of Networks Management Systems. II International Scientific and Practical Conference "Theoretical and Applied Aspects of Device Development on Microcontrollers and FPGAS" MC\&FPGA-2020: Kharkiv, June 25-26, 2020. - Kharkiv, KhNURE, 2020, Ukraine. In press. 